\title{
Strategi Pemasaran Jasa Balik Nama Sertifikat Tanah di Kantor Notaris Etik Pudji Lestari, S.H., M.Kn
}

\author{
Land Certificate Transfer Services Marketing Strategy \\ at the Notary Office Etik Pudji Lestari, S.H., M.Kn
}

\author{
Novita Setyoningrum ${ }^{1}$, Wulan Destari Natalia ${ }^{2}$ \\ ${ }^{1}$ Fakultas Ilmu Sosial dan Politik, Universitas Islam Balitar \\ Jl. Majapahit No.2-4 Blitar, Indonesia \\ ${ }^{2}$ Fakultas Ilmu Sosial dan Politik, Universitas Islam Balitar \\ Jl. Majapahit No.2-4 Blitar, Indonesia \\ E-mail: novitaset@gmail.com
}

\begin{abstract}
ABSTRAK
Bauran pemasaran adalah salah satu aspek yang dipertimbangkan oleh pembeli untuk dapat memutuskan pembelian sebuah produk baik barang ataupun jasa. Jasa disebut juga sebagai pemberian atas kinerja ataupun kegiatan yang tidak kasat mata dari suatu pihak ke pihak lain. Kantor Notaris/PPAT Etik Pudji Lestari, SH., MKn telah menerapkan 7P dengan aktivitasi berupa product, price, place, promotion, people, process serta physical evindence dalam marketing mixnya sehingga membantu mendorong minat klien untuk mengurus balik nama sertifikat pada Notaris/PPAT Etik Pudji Lestari, SH., MKn. Dalam merencanakan bauran pemasaran perlu tahapan yang berurutan dengan menitikberatkan pada keadaan yang dimiliki oleh perusahaan tersebut. Berhasil atau tidaknya program pemasaran yang dilaksankan sebuah perusahaan bergantung pada bagaimana perusahaan mampu membangun program pemasaran yang memiliki efektifitas dan efisiensi yang baik bagi terlaksananya pemasaran produk.
\end{abstract}

Kata Kunci : Balik nama, Bauran Pemasaran, Notaris

\section{ABSTRACT}

The marketing mix is one of the aspects considered by the buyer to be able to decide on the purchase of a product, both goods and services. Services are also referred to as the provision of performance or invisible activities from one party to another. The Notary Office / PPAT Etik Pudji Lestari, SH., MKn has implemented $7 P$ with activities in the form of product, price, place, promotion, people, process and physical awareness in its marketing mix so as to help encourage client interest to take care of returning the name of the certificate to the Notary / PPAT Ethics Pudji Lestari, SH., MKn. In planning the marketing mix, it is necessary to have sequential stages with an emphasis on the circumstances owned by the company. The success or failure of a marketing program carried out by a company depends on how the company is able to build a marketing program that has good effectiveness and efficiency for the implementation of product marketing.

Keywords : Behind the name, Marketing Mix, Notary 


\section{PENDAHULUAN}

Setiap perusahaan yang bergerak pada bidang penjualan barang ataupun jasa ketika melakukan aktivitas bisnisnya memiliki tujuan agar mendapatkan keuntungan. Memaksimalkan keuntungan artinya perusahaan harus bisa memaksimalkan pemasarannya. Istilah pemasaran berdasarkan buku yang berjudul Principle of Marketing karya Kotler dan Armstrong (2004) adalah "marketing is a social and administrative cycle whereby people and gatherings acquire what they need and what through making and trading items and incentive with others". Berdasarkan pengertian tersebut maka dapat disimpulkan bahwa pemasaran adalah sebuah kegiatan sesorang ataupun organisasi yang terdiri dari menyalurkan barang atau jasa, dianatara organisasi bisnis ataupun organisasi dan konsumen agar memperoleh sesuatu yang dibutuhkan dan keinginanya melalui tahapan penciptaan, penawaran, dan pertukaran produk dengan pihak lainya.

Disamping itu perusahaan punya keingian untuk dapat menghadirkan kepuasan pada konsumen dari produk yang telah dihasilkan, dikarenakan kepuasan dari konsumen merupakan sebuar standar berhasilnya perusahaan untuk menciptakan produk yang memiliki kualitas, dan yang sesuai keinginan dari konsumen. Untuk tercapainya strategi pemasaran secara tepat dan baik dalam penerapanya, maka perusahaan dapat memperhatikan aspek bauran pemasaran. Hal ini penting dikarenakan bauran pemasaran adalah faktor yang akan dipertimbangkan oleh konsumen untuk pengambilan keputusan sesurang untuk membeli sebuah produk.

Kotler dan Keller dalam Benyamin Molan (2012) menyatakan bahwa bauran pemasaran atau marketing mix merupakan seperangkat saran memasarkan produk yang berguna dalammencapai tujuan pemasaran perusahaan. Definis lain dari Buchari Alma (2012), mengatakan bahwa bauran pemasaran adalah strategi menambahkan aktivitas-aktivitas memasarkan produk, untuk dapat mengkombinasikan dengan optimal agar mendapatkan hasil yang memadai. Bauran pemasaran teradapat 4 (empat) elemen yang kemudian disingkat dengan 4P, yakni product, price, place, promotion.

Apabila sebuah perusahaan tidak memiliki kepeakaan terhadap kebutuhan dari konsumen, maka perusahaan tersebut dipastikan akan kehilangan kesempatan 
dalam mendapatkan pelanggan serta produk dijual akan tidak berarti lagi. Pada rencana pemasaran yang modern sebagian perusahaan berpatokan pada bauran pemasaran untuk perancangan program pemasaran perusahaan. Untuk menyukseskan bauran pemasaran berdasarkan product, price, place dan promotion perusahaan memiliki peran yang krusial agar program pemasaran dapat berjalan dengan sukses.

Melalui penyusunan rencana pada empat bauran pemasaran tentu saja perusahaan menginginkan rumusan program pemasaran yang tepat untuk produk yang akan dipasarkan pada konsumen. Tahapan memasarkan produk diawali dengan memenuhi apa yang dibutuhkan oleh konsumen dan selanjutnya berkembang menjadi apa yang diinginkan oleh konsumen. Misalkan, apabila sesorang butuh nasi untuk mencukupi kebutuhanya agar tidak lapar, maka ketika terdapat satu piring nasi yang didapatkan menjadi terpenuhi apa yang jadi kebutuhanya. Tetapi, seseorang juga menginginkan tidak hanya apa yang jadi kebutuhanya tetapi juga terpenuhi apa yang diinginkan.

Proses dalam memenuhi apa yang dibutuhkan dan diinginkan oleh sesorang ini menjadi lata belakang munculnya konsep pemasaran. Diawali dari produk (product), menetapkan harganya (price), mengirim produk (place), sampai dengan promosi produk (promotion). Pemasaran menjadi aktivitas yang krusial untuk dilaksanakan oleh para pengusaha sebagai upaya agar usahanya dapat bertahan serta memastikan keberlangsungan dari usahanya. Dalam perkembanganya, dunia bisnis di era globalisasi sekarang ini dituntut dengan kinerja yang maksimal berdasarkan dari proses yang perusahaan jalankan. Saat ini pemasaran tidak lagi dilihat sebagai komponen yang terpisah dari perusahaan yang memiliki peran sebagai tahapan dalam penjualan jasa.

Inti dari pemikirian pemasaran modern adalah terciptanya nilai dan bagaimana dapat memuaskan konsumen. Aktivitas pemasaran bertujuan untuk memikat konsumen dengan menjanjikan nilai yang tepat serta upaya agar konsumen tetap bertahan dengan pemenuhan terhadap keinginanya agar dapt tercipta peningkatan kepuasan konsumen. Maka dari itu, peneliti tertarik untuk meneliti lebih dalam terkait pemasaran jasa balik nama sertifikat tanah di Kantor Notaris Etik Pudji Lestari, SH., MKn. 


\section{METODE PENELITIAN}

Lokasi penelitian ini ada di Jalan Raya Sawahan Nomor 18, Desa Pojok, Kecamatan Garum, Kabupaten Blitar. Penelitian ini akan dilaksanakan di Kantor Notaris/PPAT Pojok Garum, Jalan Raya Sawahan Nomor 18, esa Pojok, Kecamatan Garum, Kabupaten Blitar. Sedang alasan peneliti memilih tempat di Kantor Notaris/PPAT Pojok Garum adalah keingintahuan peneliti terhadap pelaksanaan pelayanan jasa kepengurusan balik nama sertifikat di Notaris/PPAT Pojok Garum. Yang menjadi responden yang digunakan oleh peneliti yaitu pihakpihak yang berkaitan ataupun yang berhubungan dengan permasalahan yang akan diteliti diantaranya: pengelola, 6 pegawai dan pengguna jasa di Kantor Notaris/PPAT Pojok Garum.

Terdapat dua sumber data yang digunakan, yakni data primer dan data sekunder. Data primer adalah data yang berasal dari pengolahan yang dilakukan oleh peneliti atau data yang didapatkan dengan langsung oleh perorangan atau suatu organisasi melalui objek untuk pengumpulanya. Data primer didapatkan berdasarkan observasi secara langsung di perusahaan dan melalui wawancara. Sedangkan data sekunder adalah data yang didapatkan dari pihak lain dan tidah diperoleh sendiri pada proses mengumpulkanya. Data sekunder didapatkan dengan bentuk yang telah dikelola terkait tempat penelitian, literatur terkait penelitian dan data lainnya yang diambil dari tempat penelitian.

Guna mendapatkan data yang cukup dari Kantor Notaris/PPAT di Kabupaten Blitar yang sesuai dengan bidang yang akan dialami, maka digunakan cara pengumpulan data melalui :

1. Metode Observasi: yaitu pendekatan pengumulan data melalui mengamati secara langsung kegiatan sehari-hari pelaksanaan pelayanan di Kantor Notaris dan PPAT Kabupaten Blitar

2. Metode Dokumentasi: merupakan pendekatan pengumpulan data melalui pencarian data dalam hal-hal atau variabel dengan cara meneliti dan mencatat dokumen yang ada di Kantor Notaris /PPAT Kabupaten Blitar

3. Metode Interview: merupakan teknik mengumpulkan data melalui tanya jawab bertanya secara langsung dengan kepada sumber data, yaitu Notaris, Staff Notaris, dan Klien. 


\section{HASIL DAN PEMBAHASAN}

Terdapat komponen-komponen yang mempengaruhi terhadap marketing mix atau bauran pemasaran serta penerapanya. Dalam merencanakan bauran pemasaran dibutuhkan proses yang berurutan dengan mempertimbangkan keadaan yang ada pada perusahaan tersebut. Berhasil atau tidaknya program pemasaran yang dilaksanakan oleh perusahaan bergantung pada penyusunan program pemasaran yang tepat serta memiliki efektifitas dan efisiensi dalam pelaksanaan pemasaran produk.

Aktifitas yang dimungkinkan dapat dilaksanakan perusahaan untuk mensukseskan pemasaran produk dan diterima oleh konsumen diantaranya dengan melaksanakan rencana dalam menetapkan harga yang sesuai, ketepatan dalam menggunakan media untuk mempromosikan produk dan cocok untuk calon konsumen, serta produk yang berkualitas dan memilih penyaluran pendistribusian yang tepat dalam menyalurkan produk perusahaan. Maka dari itu, semua SDM yang ada pada perusahaan mendapatkan peran yang sangat penting untuk terlaksananya segala aktifitas perusahaan.

Untuk meningkatkan daya tarik klien dalam kepengurusan jasa balik nama sertifikat Kantor Notaris/PPAT Etik Pudji Lestari, SH., MKn melakukan kegiatan pemasaran Notaris yaitu dengan menerapkan strategi marketing mix atau bauran pemasaran. Notaris dapat diartikan sebagai lembaga penyedia produk jasa, maka bauran pemasaran yang digunakan adalah 7P yakni: produk, price, place, promotion, people, process, serta physical evidence. Implementasi dari 7P tersebut mampu membantu dan mendukung minat klien untuk megurus balik nama sertifikat pada Kantor Notaris/PPAT Etik Pudji Lestari, SH, MKn. Berikut ini merupakan penerapan $7 \mathrm{P}$ pada setiap tahapan balik nama sertifikat pada Kantor Notaris/PPAT Etik Pudji Lestari, SH, MKn.

\section{Produk (Product)}

Product merupakan segala sesuatu yang bisa ditawarkan kepada pasar agar terjadi kepuasan dari keinginan ataupun yang dibutuhkan, termasuk barang fisik, jasa, pengalaman, acara, orang, tempat, properti, organisasi, informasi dan ide (Kotler dan Keller, 2009). Produk jasa Notaris/PPAT diantaranya balik nama sertifikat tanah (Jual Beli, Hibah, Akta Pemberian Hak Bersama (APHB)), Akta 
Pemberian Hak Tanggungan (APHT), Akta Pendirian lembaga, Warmeking, Akta Hutang Piutang Bank, yang ditawarkan ke klien.

Produk juga dapat diartikan sebagai sesuatu yang ditawarkan guna pemenuhan kebutuhan. Agar dapat terpenuhi kebutuhanya klien, Notaris/PPAT Etik Pudji Lestari, SH., MKn. menyediakan jasa berupa pembuatan akta resmi yang berhubungan dengan hutang piutang di bank, maupun tanah yang diberikan pada masyarakat. Terdapat beberapa bentuk layanan jasa yang diberikan oleh Notaris/PPAT pada nasabahnya. Salah satu bentuk jasa yang diberikan oleh Notaris/PPAT adalah Balik nama sertifikat tanah. Kemudian strategi produk yang paling paling diutamakan dari Kantor Notaris/PPAT Etik Pudji Lestari, SH, MKn adalah melalui pemberian layanan dan fasilitas yang diperoleh oleh pengguna jasa. Dikarenakan produk yang ditawarkan berupa jasa, maka untuk melakukan bisnisnya Kantor Notaris/PPAT Etik Pudji Lestari, SH., MKn memerlukan perhatian terkait pelayanan yang dilaksankan oleh karyawan utnuk klien serta menegaskan bahwa karyawannya telah melaksanakan tugas dengan baik dalam pemberian pelayanan pada klien. Dalam strategi produk pelayanan pada konsumen menjadi fokus utama di Notaris/PPAT Etik Pudji Lestari, SH., MKn.

Dalam konteks kualitas jasa balik nama sertifikat tanah, pelayanan jasa dapat berbentuk semua fasilitas baik berupa jasa yang berwujud secara fisik ataupun non-fisik yang diberikan pada konsumen potensial agar dapat terpenuhi apa yang dibutuhkan dana pa yang diinginkan konsumen. Hal ini mengakibatkan fasilitas untuk layanan balik nama sertifikat tanah harus terlaksana dengan sebaikbaiknya dan konsisten untuk menciptakan tujuan serta keunggulan dari proses balik nama sertifikat tersebut, yaitu dengan mudah dan cepat tidak memakan waktu yang cukup lama.

\section{Harga (Price)}

Salah satu bagian yang penting dalam bauran pemasaran adalah price atau harga. Dari harga inilah akan ditentukan terjual atau tidak sebuah jasa yang ditawarkan oleh Notaris/PPAT. Sebagai usaha yang bergerak pada jasa yang merupakan bagian dari aktivitas ekonomi, tentunya prinsip-prinsip serta politik dalam ekonomi dipikirkan dengan serius oleh Notaris/PPAT. Menentukan harga adalah elemen yang penting untuk bisnis dibidang jasa. Dari perspektif 
pengusaha, aktivitas ekonomi secara umum dapat dimaknai sebagai kegiatan untuk memperoleh penghasilan yang maksimal dengan modal yang minimal, dan hal tersebut bisa diaplikasikan dalam berbagai bentuk.

Untuk harga di Kantor Notaris/PPAT Etik Pudji Lestari, SH., MKn juga berharap untuk dapat hasil yang maksimal, akan tetapi digunakan juga prinsip dari sedikit demi sedikit kemudian menjadi bukit serta terjadi perilaku suka terhadap produk yang ditawarkan, ataupun dapat melakukan penawaran harga antara pihak Notaris/PPAT dengan klien. Hal tersebut sekiranya dapat dimanfaatkan untuk pengendalian pergerakan bisnis dibidang jasa Notaris.

Menentukan harga merupakan hal yang penting untuk diperhatikan, karena ketika salah dalam penentuan harga maka mengakibatkan resiko yang fatal terhadap produk yang pasarkan. Harga di Kantor Notaris/PPAT Etik Pudji Lestari, SH., MKn sesuai dengan jenis kepengurusan balik nama seperti Jual beli, Hibah, Waris, Akta Pemberian Hak Bersama, letak obyek, luas obyek. Apabila klien yang sudah beberapa kali mengurus balik nama sertifikat menggunakan jasa dari Kantor Notaris/PPAT Etik Pudji Lestari, SH., MKn akan diberikan diskon harga kepengurusan balik nama sertifikat di Notaris/PPAT Etik Pudji Lestari, SH., MKn, maka harga dapat bersaing tanpa adanya pengurangan layanan yang diberikan kepada pelanggan.

Selain itu strategi menurunkan harga yang cocok dengan klien, perlu perhatian juga terhadap layanan yang diberikan ke klien, karean klien juga memiliki pandangan yang sama dengan pengusaha yakni menginginkan fasilitas dan layanan yang baik dan memuaskan dengan biaya yang rendah.

\section{Promosi (Promotion)}

Dalam promotion meliputi seluruh aktivitas perusahaan dalam mengenalkan produk dan memiliki tujuan untuk meningkatkan ketertarikan konsumen agar melakukan pembelian (Sumarni dan Soeprihanto, 2005). Kegiatan promosi difokuskan untuk mempercepat peningkatan permintaan dari produk yang ditawarkan melalui hubungan antara penjual dan pembeli. Aktivitas pada promosi memerlukan informasi mengenai produk yang akan dipasarkan. Dari makna yang sederhana, mempromosikan produk dapat berarti mengiklankan atau pariwara.

Strategi promosi di jasa Notaris/PPAT Etik Pudji Lestari, SH., MKn dengan 
memberitahukan pada klien atau masyarakat tentang jasa Notaris/PPAT Etik Pudji Lestari, SH., MKn, biasanya promosi yang dilakukan bisa secara langsung maupun tidak langsung. Agar target penjualan dapat tercapai, perusahaan dituntut untuk lebih fokus pada komunikasi dengan pelangaan melalui produk yang dipasarkan. Penentu keberhasilan dari program pemasaran dipengaruhi oleh promosi yang dilakukan perusahaan. Sebagus-bagusnya produk yang ditawarkan jika konsumen tidak pernah mendapatkan informasi atau yakin terhadap produk tersebut, maka konsumen juga tidak akan melakukan pembelian atau memakai jasa dari perusahaan tersebut.

Strategi dalam meningkatkan masyarakat agar loyal atau adanya loyalitas maka sistem di kantor Notaris/PPAT Etik Pudji Lestari, SH., MKn menerapkan teknik langsung dengan metode menjemput bola atau door to door, dilakukan dengan dating ke Bank-Bank yang ada di kota tersebut, atau ke kantor pemasaran perumahan-perumahan yang membutuhkan jasa kepengurusan balik nama. Sedangkan pemasaran yang tidak secara langsung memakai Banner. Akan tetapi di Kantor Notaris/PPAT Etik Pudji Lestari, SH., MKn belum punya website dan jejaring sosial untuk promisi, yang fokus untuk melakukan pemasaran, tetapi dengan door to door atau secara langsung akan tertanam brand image agar keberadaannya akan lebih dikenal. Sehingga, apabila brand image telah ditanamkan pada benak masyarakat, akan berakibat memudahkan penjualan baik penjualan dalam bentuk barang ataupun jasa.

Promosi memiliki tujuan utama untuk memperkenalkan aktivitas usaha yang dilakukan pada masyarakat. Apabila promosi dilakukan dengan gencar, maka semakin kuat citra produk yang dipasarkan. Hal ini disebabkan karena kegiatan promosi memperlihatkan semua kelebihan yang ada pada perusahaan. Strategi marketing Kantor Notaris/PPAT termasuk dalam salah satu strategi promosi. Usaha-usaha Notaris/PPAT Etik Pudji Lestari, SH., MKn untuk meningkatkan dalam promosinya Kantor Notaris/PPAT tersebut selalu menepati janji dalam pembuatan akta, Merahasiakan kepercayaan klien (memegang rahasia klien), Memberikan bimbingan dan nasehat hukum terhadap klien jika diperlukan, Tersedianya fasilitas hiburan seperti majalah serta bahan bacaan di ruang tunggu, Memberikan pelayanan dengan ramah terhadap klien ataupun terhadap tamu yang 
datang.

\section{Tempat (Place)}

Pendekatan tempat dapat berarti sebagai memilih lokasi usaha dan memilih lokasi untuk melayani segala aktivitas bisnis. Makna dari definisi tersebut sangat penting. Karena, tempat untuk bisnis yang bergerak dibidang jasa adalah penggabungan antara lokasi dan keputusan untuk jaringan distribusi, dalam hal ini berhubungan dengan teknik dalam menyampaikan layanan jasa pada konsumen dan dimana tempat yang strategis. Tempat pelayanan jasa yang dipakai untuk pasokan jasa pada pelanggan adalah keputusan yang penting. Memutuskan terkait tempat layanan yang akan digunakan melibatkan berbagai pertimbangan, diantaranya bagaimana menyerahkan jasa dan dimana tempatnya. Hal ini menunjukkan bahwa lokasi memiliki peran penting sebagai lingkungan untuk menyerahkan jasa dan untuk memberikan nilai dan manfaat dari jasa.

Strategi tempat yang dilakukan oleh Kantor Notaris/PPAT Etik Pudji Lestari SH., MKn, mengenai tempat yaitu dengan dilakukan pemilihan lokasi yang strategis akan tetapi terjangkau untuk masyarakat, berdekatan dengan Kantor Dinas Pendidikan Kabupaten Blitar, terletak di Jalan Raya Sawahan Nomor 50, jalan raya yang meruoakan jalur provinsi, kurang lebih sekitar 100 meter dari tugu perbatasan atara Kota Blitar dengan Kabupaten Blitar.

Maka pemilihan lokasi yang strategis menjadi sangat penting, dikarenakan lokasi usaha memiliki kaitan dengan obyek wilayah lokasi tanah. Pada Kantor Notaris/PPAT Etik Pudji Lestari, SH., MKn memilih wilayah kerja pada Kabupaten Blitar, karena pada awal tahun 2011, belum terlalu banyak Notaris/PPAT yang membuka kantor pada wilayah Kabupaten Blitar.

\section{Orang (People)}

Sebuah perusahaan yang bergerak dibidang jasa dapat memiliki kelebihan dari kompetitornya, apabila dapat merekrut dan memberikan pelatihan kepada karyawanya yang lebih baik dan lebih handal dalam berkomunikasi dengan pelanggan. Orang dalam hal ini merupakan seluruh pelaku yang memiliki peranan dalam memberikan jasa hingga dapat memberikan pengaruh terhadap presepsi konsumen. Komponen dalam people antara lain karyawan, konsumen, serta konsumen lainya yang berada dalam lingkungan jasa. Seluruh perilaku serta 
penampilan karyawan memiliki pengaruh terhadap persepsi dari konsumen atau tingkat keberhasilan dari penyampaian jasa (service encounter). Seluruh orang yang terlibat dan berperan dalam menyajikan jasa akan mempengaruhi persepsi pembeli. Yang masuk ke dalam komponen ini diantaranya karyawan perusahaan dan konsumen lain dalam lingkungan jasa.

Strategi Orang (people) yang di lakukan di Kantor Notaris/PPAT Etik Pudji Lestari, SH., MKn pada tahapan seleksi karyawan, memberikan pelatihan, dan memberikan motivasi pada karyawan yang selanjutnya dipergunakan untuk menjadi kelebihan perusahaan dalam memberikan kepuasan konsumen. Karyawan merupakan orang yang bekerja secara langsung dan tidak langsung yang nantinya memberikan layanan dan kepuasan layanan kepada konsumen atau klien Notaris/PPAT Etik Pudji Lestari, SH., MKn.

Orang memiliki peran pada perusahaan jasa dikarenakan orang terlibat secara langsung dalam penyampaian produk ke konsumen. Walaupun dengan berkembangnya teknologi, fungsi orang dalam melayani konsumen tidak tergantikan. Orang menjadi aset utama pada dunia industri jasa, terlebih lagi orang sebagai karyawan memiliki kinerja yang sangat baik. Karyawan yang memiliki performa yang baik akan meningkatkan kepuasan dan loyalitas pelanggan. Kaeyawan dengan kemampuan pengetahuan (knowledge) yang baik, akan menjadi kompetensi dasar dalam internal perusahaan dan citra yang baik bagi perusahaan.

Strategi Orang (people) yang di lakukan Kantor Notaris/PPAT Etik Pudji Lestari, SH., MKn pada tahapan seleksi karyawan, memberikan pelatihan, dan memberikan motivasi pada karyawan yang selanjutnya dipergunakan untuk menjadi kelebihan perusahaan dalam memberikan kepuasan konsumen dengan produk. Jasa pelayanan pada Kantor Notaris/PPAT Etik Pudji Lestari, SH., MKn ketika melayani pelanggan dituntut untuh ramah, tanggap, murah senyum, serta cekatan. Dan di Kantor Notaris tersebut memilih karyawan yang minimal lulusan SMA atau SMK (fresh graduate). Karena agar mudah dibentuk karakternya sesuai dengan apa yang akan mereka kerjakan.

6. Proses (Process)

Mutu pelayanan bidang jasa sangat tergantung pada proses dalam menyampaikan jasanya pada pelanggan. Proses menjadi salah satu elemen 
tambahan bauran pemasaran yang memiliki perhatian serius dalam perkembangan dunia pemasaran. Perlu diingat bahwa untuk menggerakan perusahaan jasa adalah karyawan, maka agar terjamin mutu pelayanan atau quality assurance pada keseluruhan operasional perusahaan harus menjalankan fungsinya sesuai dengan sistem dan prosedur yang telah memiliki standar tertentu oleh karyawan yang memiliki kompetensi, komitmen, dan loyalalitas terhadap perusahaan dimana mereka bekerja.

Strategi Proses pada jasa yang dilakukan Kantor Notaris/PPAT Etik Pudji Lestari, SH., MKn untuk memasarkan jasa kepada klien balik nama sertifikat tanah adalah dengan menggunakan sistem. Sistem tersebut dapat terlihat dalam menilai apakah telah memiliki kecepatan ataupun masih lambat dalam layanan di Kantor Notaris/PPAT Etik Pudji Lestari, SH., MKn. Karena jika kita menjadi klien tentu saja menginginkan untuk memperoleh layanan dengan cepat dan memuaskan. Selain itu terdapat kreativitas untuk menggunakan teknologi, apabila terdapat konsumen yang merasa tidak puas dari pelayanan yang diberikan Kantor Notaris/PPAT Etik Pudji Lestari, SH., MKn maka konsumen dapat melakukan complain secara langsung kepan Notaris, atau memberi teguran kepada para karyawan disana, agar segera diselesaikan permasalahannya.

Maka, seluruh kegiatan kerja adalah proses yang melibatkan prosedur, penjadwalan, pemberian tugas dan mekanismenya, serta kegiatan yang bersifat rutin. Bagian proses yang menjadi pemahaman bagi konsumen dan sesuai dengan yang dijanjikan akan berperan dalam menentukan kepuasan pelanggan. Proses menjadi salah satu komponen yang memiliki peran sangat penting dalam perkembangan jasa Notaris/PPAT sehingga mampu menghasilkan produk dalam bentuk jasa yang prosesnya dapat berjalan secara efektif dan efisien, disamping itu juga dapat diterima oleh konsumen dengan baik.

\section{Bukti Fisik (Physical Evidance)}

Bentuk fisik dari perusahaan memiliki pengaruh terhadap konsumen agar dapat melakukan pembelian atau menggunakan produk jasa yang dipasarkan dan merupakan lingkungan fisik dimana jasa ditawarkan, perusahaan jasa dan konsumennya berinteraksi dan setiap bagian yang berwujud memfasilitasi penampilan atau komunikasi jasa tersebut. Strategi Bukti fisik atau pemberian 
bukti oleh Kantor Notaris/PPAT Etik Pudji Lestari, SH, MKn yang ditujukan kepada klien sebagai usulan nilai tambah klien atau wujud nyata yang ditawarkan kepada pelanggan ataupun calon pelanggan jasa dari Kantor Notaris/PPAT Etik PUdji Lestari, SH., MKn. Bukti nyatanya pelayanan dari Kantor Notaris/PPAT tersebut menjadikan klien nyaman puas dengan jasa pelayanannya, seperti rasa yang dirasakan klien, sesuatu hal yang bersifat in-tangible yang tidak bisa diukur secara pasti.

Building adalah komponen dari bukti fisik, karakteristik yang menjadi persyaratan yang bernilai tambah bagi klien pada perusahaan jasa balik nama sertifikat rumah yang berkarakter. Perhatian terhadap interior, perlengkapan bangunan, termasuk lightning system, dan penataan ruangan yang lebar menjadi perhatian penting dan bisa mempengaruhi susasana hati konsumen. Bangunan harus mampu menciptakan suasana yang nyaman sehingga perusahaan dapat menciptakan layanan yang memiliki kualitas yang baik perlu memperhatikan elemen layanan.

\section{KESIMPULAN DAN SARAN}

Penelitian ini memiliki tujuan agar dapat diketahui strategi pemasaran diantaranya produk, harga, promosi, tempat, orang, dan bukti fisik pada layanan yang bergerak dibidang jasa balik nama sertifikat tanah dan dapat ditarik kesimpulan, yaitu: pelayanan pada konsumen harus lebih memperhatikan strategi produk yang dilakukan di Notaris/PPAT Etik Pudji Lestari, SH., MKn. Strategi harga dilakukan dengan memberikan diskon harga untuk klien yang sudah beberapa kali mengurus balik nama sertifikat. Strategi promosi yaitu dengan door to door dan menggunakan banner. Strategi tempat dilakukan dengan memilih kantor yang lokasinya strategis dan bisa terjangkau oleh masyarakat. Strategi orang dilakukan dengan memilih karyawan yang minimal lulusan SMA atau SMK. Strategi proses diberikan dengan jasa layanan yang efektif dan efisien. Bukti fisik diberikan melalui bangunan yang menciptakan suasana nyaman untuk para pelanggan di kantor Notaris/PPAT Etik Pudji Lestari, SH., MKn.

Dari kesimpulan yang didapatkan, maka untuk saran sebagai usulan yang dapat dijadikan perbaikan diantaranya : 
1. Kantor Notaris/PPAT Etik Pudji Lestari, SH., MKn harus dapat mempertahankan dan melakukan peningkatan terhadap minat klien agar menggunakan jasanya dengan mempromosikan Notaris/PPAT Etik Pudji Lestari, SH, MKn di lembaga seperti Perbankan, Koperasi, ataupun PerusahanPerusahan yang membutuhkan jasa notaris. Sehingga para calon klien tahu seperti apa kualitas yang dimiliki oleh Kantor Notaris/PPAT Etik Pudji Lestari, SH., MKn. Perlu adanya kesadaran bahwa menjaga konsumen untuk tetap bertahan jauh lebih baik dan bermanfaat apabila dibandingkan dengan mencari konsumen baru untuk menjadi pelanggan, oleh karena itu perusahaan perlu untuk lebih memerhatikan layanan pada pelanggannya.

2. Pada saat notaris berada di luar untuk kegiatan lapangan atau ada undangan dinas sehingga membuat penundaan untuk penandatanganan dapat diwakili oleh staf yang menjadi kepercayaan notaris dan sepengetahuan notaris.

\section{DAFTAR PUSTAKA}

Alma, Buchari. (2012). Menejemen Pemasaran dan Jasa. Bandung: Alfabeta Kotler, Philip dan Amstrong, Gary. (2004). Prinsip-Prinsip Pemasaran Edisi ke12 Jilid 1. Jakarta: Erlangga.

Kotler, Philip dan Keller, Kevin Lane. (2009). Manajemen Pemasaran Edisi ke13. Jakarta: Erlangga. .. (2012). Manajemen Pemasaran Alih Bahasa: Benyamin Molan. Jakarta: Erlangga.

Sumarni, Murti dan Soepriharto, John. (2005). Pengantar Bisnis. Yogyakarta: Liberty. 